\title{
THE PUFF-PASTRY MAKING PROPERTIES OF TRITICALE FLOUR
}

\author{
B. Czank ${ }^{1}$, Ács péterné $^{1}, Z z s$. Kovács ${ }^{1}, E_{\text {..,Cs. Czankné }}{ }^{2}$ L. Bóna ${ }^{1}$ \\ ${ }^{1}$ Cereal Research Non-Profit Ltd., H-6701, POB 391 Szeged, Hungary \\ ${ }^{2}$ Fodor József Food Industry Vocational High School, H-6725 Szabadkai street 3., Szeged, \\ Hungary \\ e-mail: bernadett.czank@gabonakutato.hu
}

\begin{abstract}
The flour $(100 \% \mathrm{Tc})$ of the triticale variety GK Szemes bred at the Cereal Research NonProfit Ltd. was tested for food purposes, namely, for puff-pastry making properties. The control dough was made of BL 55 plain wheat flour (100\% BL). Flour mixtures (flour mixtures I and II) were prepared by mixing wheat flour and triticale flour to different ratios. The flours, their mixtures, and the puff-pastry made of them, respectively, were analyzed according to the terms of the Hungarian Food Codex for the following rheological traits: gluten content, falling number, farinograph water absorption, and extensibility. The data reflected that the triticale flour and wheat flour mixtures had advantageous baking industrial properties. The dough of flour mixtures was easier to handle manually than the control. The dough on flour mixture II basis was ranked higher than that of flour mixture I in terms of sensory properties. Therefore flour mixture II had been chosen to bake Chelsea bun-type puffpastry with savoury (pizza cream) flavouring. Triticale has favourable agronomic traits and beneficial nutrition value and therefore it is expected to become a valuable food component.
\end{abstract}

Keywords: triticale, flour mixture, puff-pastry

\section{INTRODUCTION}

Triticale (x triticosecaleWittmack), the outcome of the crossing of wheat and rye was created at the end of the 19th century. In Hungary the cultivation started in the late 1980s, mainly for the use to feed animals. Nowadays as healthy eating has gained importance, it is more and more often used as human nutriment. The registered triticale varieties of the Cereal Research Non-Profit Ltd. (GK Idus, GK Rege, and GK Szemes), have excellent agronomic characteristics, which means, that they would become important elements of agricultural production. Some nutritional parameters fall between wheat and rye values, in some cases, even exceeding these values which can establish the use of human nutriment. The gluten composition of wheat improves the technological properties, the pentozans of rye improve water absorption and preservation which all, increase nutritional value. Triticale bread can cover $60 \%$ of the necessary daily fibre intake while this is only $30 \%$ in case of white bread. Bread made of triticale is richer in minerals (Ács and Bóna, 2013). Further studies were carried out abroad to find out whether the antioxidant content of triticale allows the use of triticale as supplementary or functional food (Hosseinian and Mazza, 2008). They led us to examine how triticale could be used in producing bakery, and to examine what are the parameters when used in itself or mixed with wheat flour. 


\section{MATERIALS AND METHODS}

In our work the flour $(100 \% \mathrm{Tc})$ of the triticale variety GK Szemes bred at the Cereal Research Non-Profit Ltd. was tested for food purposes, namely, for puff-pastry making properties. The control dough was made of BL 55 plain wheat flour $(100 \% \mathrm{Bl})$. Flour mixtures (flour mixtures I. and II.) were prepared by mixing wheat flour and triticale flour to different ratios. The Flour mixture I was $60 \%$ BL- $40 \%$ Tc, the Flour mixture II was $40 \%$ BL$60 \%$ Tc. The flour mixtures were analyzed according to the terms of the Hungarian Food Codex for the following rheological traits: gluten content (MSZ EN ISO 21415-2:2008, washing machine), falling number (MSZ EN ISO 3093:2010, HagbergPerten's definition), water absorption (MSZ ISO 5530-1:2003, With BrabenderFarinograph), extensibility (MSZ ISO 5530-2:2007, with Brabenderextenzograph). Puff-pastry base were made of different flour samples (FodorJózsef Food Industry Vocational High School, Szeged). The puff-pastry base was made without flavouring. The main ingredients were flour, margarine, yeast, salt, sugar, milk powder, egg powder, and water. The laminated dough was prepared by the usual rolling and folding method ( 1 simple, 1 double). It was baked at $180^{\circ} \mathrm{C}$ for $10-15$ minutes in rotating tray oven. The baked product was evaluated by a group of students ( 15 students) by simple descriptive sensory methods. They evaluated the positive and negative attributes of the product, namely the colour, shape, aroma, flavour and tunes. Flavoured dough (sweet and savoury) was made of the best mixture. As a control sweet and salty puff-pastries were prepared from wheat flour $(100 \% \mathrm{BL})$. The baked products were evaluated by 50 people (GK Fórum, Szeged) the evaluation was based on sensory, 20-point weighing factor method. The group scored the shape, crust, crumb, aroma and flavour of the product from 1--5. Weighing factors were assigned to the results to stress the differences of the characteristics.

\section{RESULT AND DISCUSSION}

The flour and flour mixtures were qualified by flour testing methods. The results are shown in Table 1. The results show that if we mix triticale flour to good quality wheat flour, then the baking indicators of the mixtures may significantly improve compared to the values of triticale.

Table 1 Results of flour quality tests of triticale, wheat and their mixtures

\begin{tabular}{|c|c|c|c|c|c|c|}
\hline Type & $\begin{array}{c}\text { Gluten } \\
\text { spreading } \\
(\mathrm{mm} / \mathrm{h})\end{array}$ & $\begin{array}{l}N s \\
(\%)\end{array}$ & $\begin{array}{c}\text { Water } \\
\text { abs.(\%) }\end{array}$ & $\begin{array}{l}\text { Dough dev.tim. } \\
\text { (min) }\end{array}$ & $\begin{array}{l}\text { Stab.ICC } \\
\quad(\text { min) }\end{array}$ & $\begin{array}{l}\text { Value } \\
\text { num. } \\
\text { (-) }\end{array}$ \\
\hline $100 \% \mathrm{BL}$ & 1.75 & 30.2 & 59.8 & 4.4 & 1.7 & 74.4 \\
\hline Flour mixture. I. & 1.5 & 26.9 & 61.4 & 3.1 & 1.9 & 56.6 \\
\hline Flour mixture II. & 1.75 & 25.2 & 62.2 & 3.7 & 0.6 & 42.4 \\
\hline $100 \%$ Tc & 2 & 18.4 & 63.9 & 2.2 & 0.4 & 19.5 \\
\hline Type & $\begin{array}{l}\text { Fall. num. } \\
\quad(\mathrm{sec})\end{array}$ & $\begin{array}{c}\mathrm{E}\left(\mathrm{cm}^{3}\right) \\
135 \\
(\mathrm{~min})\end{array}$ & $\begin{array}{l}\text { Tenacity } \\
\text { (BU) }\end{array}$ & $\begin{array}{c}\text { Extensibility (E) } \\
135(\mathrm{~mm})\end{array}$ & $\begin{array}{c}\text { Max } \\
(135 \mathrm{~min}) \\
(\mathrm{Rm})\end{array}$ & $\begin{array}{c}\text { Elasticity } \\
135- \\
\text { Max } \\
(-) \\
\end{array}$ \\
\hline $100 \% \mathrm{BL}$ & 556 & 117 & 390 & 157 & 565 & 3.6 \\
\hline Flour mixture. I. & 509 & 76 & 290 & 149 & 362 & 2.4 \\
\hline Flour mixture II. & 487 & 53 & 238 & 136 & 266 & 1.9 \\
\hline $100 \%$ Tc & 408 & 37 & 224 & 113 & 235 & 2.1 \\
\hline
\end{tabular}


The wet gluten (Ns) content shows the baking suitability of flours, and $26 \%$ gluten content is an acceptable value. If the gluten content is lower, technological changes should be applied. In the flour mixture wet gluten content was surprisingly good. On the basis of falling number (556-408) (Fall.num.), the samples can be put in enzyme poor categories. Probably this might be due to the fact that there was hardly any rain in 2012. From the point of view of the current research these falling number values are acceptable. According to the farinograph, water absorption (water abs.) influences the economy of bakery productions. The triticale flour $(100 \% \mathrm{Tc})$ had very high water absorption, therefore the mixture improved by increasing the amount of triticale flour. The dough development time (dough dev. tim.) is an indicator which relates to the quality of the protein, in case of strong flour it is longer, while in case of weaker flour is shorter. Thus in the samples that contained triticale flour the dough development time was shorter (flour mixtures I. 3.1, flour mixtures II. 3.7). One of the most important parameters determined by farinograph is stability which refers to the quality of flour. Continual kneading softens pasta. The sooner this happens, the less the dough can resist mechanical effects. Flour mixture I had the best stability (Stab. ICC) (1.9) and the least the triticale flour $(100 \% \mathrm{Tc})(0.4)$, so triticale flour was found to soften earlier. This shows that bakery products made of triticale flour need shorter working/kneeding, because the dough reaches optimal consistency in shorter time, however, it also loses its consistency within a shorter time.

The bakery values of flour shows for what type of bakery products it can be used, if it can be used at all. Extensograph results show that triticale flour mixed with good quality wheat flour has better quality parameters than triticale flour in itself. In the present research, the extensogram (I., II.) of the flour mixture shows better optimum diagram than the wheat flour extensogram $(100 \% \mathrm{BL})$. That is, the ratio of the maximum point of the diagram $(\mathrm{Rm})$ and the territory under the diagram (E) is better at flour mixtures (I., II.). The examination of the quality of flours shows that the flour mixtures have good properties, because they have constant dough stability, which is typical of wheat, and short development time, which is typical of triticale and this results in significant energy saving. From the results of extensograph it is clear that the manual work with the dough is easier.

The results of making and processing puff-pastry base were as it was expected on the basis of examining flour quality. The kneading time of pasta containing triticale flour was shorter and the development of dough was quicker. The dough made of triticale flour $(100 \%$ Tc) was softer, more extensible and less elastic. Working with that dough was more difficult than with the dough containing wheat flour $(100 \% \mathrm{BL})$. The dough made of Flour mixture II was elastic and strong.

According to the sensory judgment, the puff-pastry made of Flour mixture II was unambiguously the best. This product showed all the standards of puff-pastry. Based on the results it can be established that although Flour mixtures I and II are usable for baking, for the baking of puff-pastry only Flour mixture II is recommended.

Further research with the winning flour (Flour mixture II) was carried out. Pizza pastries were prepared and were compared to the control $(100 \% \mathrm{BL})$ sample. The sensory judgements of flavoured snails showed that there was very little difference between the A (control) and B (flour mixture II.) samples, that is the judges could not differentiate the two samples (Figure 1.). 


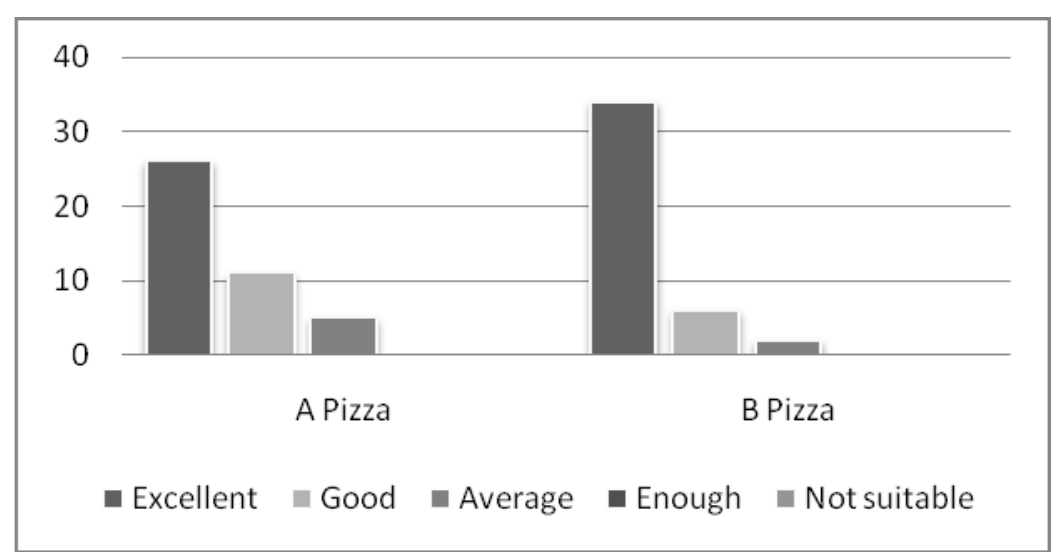

Figure 1 Result of the sensory judgement of flavoured puff-pastry

As for crumb and flavour properties results, pizza flavoured pastry made of Flour mixture II savoury snail results were better. The results showed that the triticale flour on its own is not suitable for bakery use, but mixed with wheat flour it can be used for bakery products and pastries of good properties. In case of laminated pastry, the results with mixed flour were better than that of the pastries made from $100 \%$ wheat flour.

In the present research high quality wheat flour was used, but further studies are needed with low quality wheat flour applications. It would be necessary to carry out nutritional studies for the further production of baking goods.

\section{ACKNOWLEDGEMENT}

This work the GOP-1.1.1-11-2012-0044 „A triticale humáncélratörténőkutatásaésfejlesztése” title of tender was come true with support.

\section{REFERENCES}

Ács, P., Bóna, L. (2012.): ÚjTritikáléfajtáksütőiparihasznosításilehetőségei VII. AlföldiTudományosTájgazdálkodásinapok p.: 62-67

Ács, P., Bóna, L. (2013.):. A SzegediRozsbuzakenyér Magyar Mezőgazdaság, Növénytermesztés

Hosseinian, F.S., Mazza, G., (2009): Triticale bran and straw: Potential new sources of phenolic acids, proanthocyanidins, and lignans Journal of Functional Food I (2009) 5764 